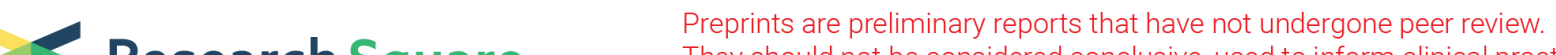 Research Square They should not be considered conclusive, used to inform clinical practice, or referenced by the media as validated information.
}

\section{The Effect of Alcoholic Extract of Thymus Vulgaris on Hepatic Enzymes Activity and Apoptosis-Related Gene Expression in Streptozotocin-Induced Diabetic Rats}

\section{Mohammadreza Azimi}

Islamic Azad University Saveh Branch

Elnaz Ahmadi

Islamic Azad University

Fatemeh Aghaie

Shahid Beheshti University of Medical Sciences School of Nursing and Midwifery

Mohammad Orafei

Ferdowsi University of Mashhad

Armita Ahmadi

Ferdowsi University of Mashhad

Ali Ghorbani Ranjbary ( $\nabla$ alighorbani.r@ut.ac.ir)

Tehran University: University of Tehran

\section{Research Article}

Keywords: Thymus vulgaris, Liver enzymes, Diabetes, Apoptosis, Rat

Posted Date: June 24th, 2021

DOl: https://doi.org/10.21203/rs.3.rs-569088/v1

License: (c) (1) This work is licensed under a Creative Commons Attribution 4.0 International License.

Read Full License 


\section{Abstract}

Many diseases, including diabetes, are involve in the development of liver disorders through changes in the expression of genes such as apoptosis-related gene. In the present study, the effect of alcoholic extract of Thymus Vulgaris on Hepatic Enzymes Activity and apoptosis-related gene expression in streptozotocin-induced diabetic rats. In this study, 50 adult male Wistar rats weighing approximately 200-220 g were divided into five groups. Diabetes was induced by intraperitoneal injection of STZ (60 $\mathrm{mg} / \mathrm{kg}$ ). Following 18 days, all the animals in different groups were weighed and blood samples were taken from their cardiac veins. GC analysis revealed 45 different compounds in the Thymus Vulgaris, including; thymol (39.1\%), p-cymene (20.63\%), y-Terpinene (14.85\%). The results showed a significant increase in liver enzymes (AST, ALT and ALP) in diabetic or streptozoic mice compared to the control group (healthy mice) $(p<0.0001)$. The level of liver enzymes (AST, ALT and ALP) in rats treated with doses $200 \mathrm{mg} / \mathrm{kg}$ and $400 \mathrm{mg} / \mathrm{kg}$ of thymus vulgaris extract showed a significant decrease in these enzymes in comparison with diabetic rats $(p<0.0001)$. The expression of caspase 3 and 9 genes in the groups treated with thyme significantly decreased compared to diabetic mice $(P<0.0001)$ and the expression of $\mathrm{Bcl}$ in the group receiving $400 \mathrm{mg} / \mathrm{kg}$ of thyme significantly increased compared to diabetic mice $(P=0.0001)$. Due to its antioxidant compounds, thyme improves the liver tissue cells in streptozotocin-induced diabetic mice by reducing caspases 3 and 9 as well as increasing Bcl-2.

\section{Introduction}

Different genetic factors leading to types I and II diabetes mellitus. Both of them are prone to complications such as nephropathy, retinopathy, peripheral nerves disorders, and blood pressure [1, 2]. Diabetes is as the leading causes of hepatic disorders in the United States of America. In many studies have shown that liver disease is an important cause of morbidity and mortality in type II diabetes [3]. Besides, the high prevalence of liver disease in diabetic patients, the incidence of diabetes is higher in patients with liver disease. It seems that the incidence of liver disease in diabetes type II occurs due to complications such as abnormal liver enzymes, non-alcoholic fatty liver, cirrhosis, hepatocellular carcinoma and acute liver failure is more prevalent [4].

Streptozotocin is a drug used in chemotherapy, and it also specifically kills pancreatic beta cells, thereby lowering insulin levels [5]. The streptozotocin model is a common method for inducing experimental diabetes in rodents and has been used repeatedly in various studies to induce type 1 diabetes $[5,6]$. Recent studies have shown that streptozotocin causes inflammation by disrupting the relationship between ROS production and radical scavenging effect $[7,8]$. The rise in the production of free radicals or ROS formation may result in oxidized LDL (Ox-LDL), a crucial step in the chain of events leading to atherosclosis sustained hyperglycemia and increased oxidative stress, which are the key players in the development of secondary diabetes problems. These abnormalities result in pathologies such as vasculopathies, neuropathies, ophthalmopathies and nephropathies, among various other medical problems [9]. Through in vitro cell culture as well as in vivo diabetic rodent models for STZ-induced toxicity, it has been shown that STZ induces cellular oxidative stress and mitochondrial respiratory 
dysfunction $[10,11,12]$. A number of experiments have been conducted to assess the changes in cell mitochondrial functions from brain, heart, liver, and kidney of diabetic rats [13]. Nevertheless, the results have been at times controversial for the reason that experimental conditions such as age and strain of used animals have been different.

The synthetic drugs for liver diseases, including corticosteroids, antiviral and immunosuppressant agents, might cause serious adverse effects up to hepatic impairment, such as cholestatic jaundice with azathioprine and elevation of serum transaminases by interferon and virazole [14]. As such, it is of paramount importance to explore other sources to treat the liver disease more effectively and safely.

Thymus vulgaris (called "wild thyme" in Persian) is a plant from Labiatae and Plantae family [15]. It grows in many parts of Europe, particularly in southern Europe, north of Africa, as well as large parts of Asia. Wild thyme is used in traditional medicine as an antiseptic, antispasmodic, anti-worm, and carminative as well as for relieving liver and bile problems $[16,17,18,19]$. Wild thyme has $1 \%$ oil and a large part of it consists of phenols, monoterpene hydrocarbons, and alcohol. Wild thyme essence generally contains 25 compounds such as thymol (26.9\%), carvacrol (40.7\%), and $y$-terpenen $(7.3 \%)$ [20, 21]. This research aimed to achieve the protection role of T. Vulgaris on Hepatic Enzymes Activity and apoptosis-related gene expression in streptozotocin-induced diabetic rats.

\section{Materials \& Methods}

\section{Collecting and Identifying the Plant}

Leaves and twigs of the wild thyme plant were collected from the areas near Shiraz, Iran, in March-April 2019 , dried at $25^{\circ} \mathrm{C}$ in the shade, and then powdered by a mechanical mill. The dried powder was kept in plastic bags in a freezer until testing.

\section{Extraction Method}

Twenty grams of the obtained powder was poured into an Erlenmeyer flask and $200 \mathrm{ml}$ of ethyl alcohol at $70^{\circ} \mathrm{C}$ was added. Next, the flask was closed by its cap and the solution was held for 48 hours, while the content of the flask was shaken once every 12 hours. Following 48 hours, the content of the flask was filtered into a beaker using a filter paper and a funnel glass. Then, the filtered solution was poured into a flask and placed in a rotary device at $75^{\circ} \mathrm{C}$ with average rotation speed. After solvent evaporation, the resultant concentrated liquid was spread on the glass surface and left to dry. The obtained powder containing approximately 2.59 percent of the concentrated extract was collected after drying. Finally, the yielded powder was used to prepare doses of 100,200 , and $400 \mathrm{mg} / \mathrm{kg}$. All the solutions were prepared by distilled water.

\section{Plant Compounds}

First, thymus vulgaris essential oil was prepared and the compounds were then isolated by GC/MS device (HP-6840/5973) in the central laboratory of Ferdowsi University of Mashhad. The constituting 
elements were identified by comparing their mass spectra with the existing standard spectra.

\section{Animals}

Small rats, each with an approximate weight of $200 \pm 5 \mathrm{~g}$, were kept in clean cages at $25 \pm 2^{\circ} \mathrm{C}$ and in a diurnal cycle of 12 hours of light and 12 hours of darkness, with relative humidity of 40-60 percent. The animals had access to water and food.

\section{Preparation of Diabetic Animals}

Streptozotocin (Pharmacia \& Upjophn, USA) $(60 \mathrm{mg} / \mathrm{kg}$ ) solved in sterile saline just shortly prior to the test was intraperitoneally injected into rats. Animals with up to 180 milligrams/deciliter of glucose level of serum were used in the test five days after the injection.

\section{Treatment Method}

The wild thyme hydroalcoholic extract was inraperitoneally used as treatment in different doses for 18 days. The number of animals in each group was 10. The first control group (Group 1) received merely regular food and water. The second control group (Group 2) received saline daily and the three experimental groups (Groups 3-5) daily and intraperitoneally received a low dose (100 mg), a medium dose $(200 \mathrm{mg})$, and a high dose $(400 \mathrm{mg})$ of wild thyme hydroalcoholic extract in two groups of healthy and diabetic for 18 days.

\section{Assay of Hepatic Marker Enzymes}

The hepatic marker enzymes such as aspartate aminotransferase (AST), alanine aminotransferase (ALT), and alkaline phosphatase (ALP) in serum were measured using diagnostic kits (Parsazmon, Iran). As such, glucose, cholesterol, HDL cholesterol in serum, as well as LDL and VLDL cholesterol were measured [22].

\section{Histopathology}

The liver tissue was fixed in $10 \%$ formalin for $48 \mathrm{~h}$. It was then followed by dehydration by passing through a series of graded alcohol, beginning with $50 \%$ alcohol and progressing in graded steps to $100 \%$ (absolute) alcohol, and was finally embedded in paraffin. Liver slices (5-6 $\mu \mathrm{m}$ thick) were prepared using a semi-automated rotator microtome, stained with Hematoxylin and Eosin dyes, and observed microscopically.

\section{RT-qPCR Assays}

Total RNA from liver tissues was extracted using the Column RNA Isolation Kit (DENAzist Asia Co., Iran) and reverse-transcribed with cDNA synthesis kit (Thermo Fisher Scientific., USA). 
The designed primers (Beacon Designer v8) were as follows: for BCL2, F: 5'- GAGCGTCAACAGGGAGA-3' and R: 5'- GCCAGGAGAAATCAAACA-3'; for BAX, F: 5'- ACTAAAGTGCCCGAGCTGA-3' and R: 5'-

ACTCCAGCCACAAAGATGGT-3'; for C3, F: 5'- GGAGCTTGGAACGGTACGCT-3' and R: 5'-

AGTCCACTGACTTGCTCCCA-3'; for C9, F: 5'- AGCCAGATGCTGTCCCATAC-3' and R: 5'-

CAGGAGACAAAACCTGGGAA-3'; for $\beta$-actin: F: 5'-ATCAGCAAGCAGGAGTACGAT-3' and R: 5'AAAGGGTGTAAAACGCAGCTC-3'.

The normalization and analyses of the qPCR data were performed using Genex Version 6 software (MultiD, Göteborg, Sweden) and Relative Expression Software Tool (REST; QIAGEN, Hilden, Germany).

\section{Statistical Data Analysis}

The collected data were analyzed using SPSS statistical software, and one-way analysis of variance (one-way ANOVA) and Tukey test at the significant level of $p<0.05$ were run to investigate between-group differences. All results were presented as Standard Error of Mean (SEM).

\section{Results}

The main compounds of thyme essential oil measured by GC/MS are shown in Table 1. Identification of compounds has been done by comparing their mass spectra with their mass indices with the reference spectrum and also comparing their inhibition indices with the inhibition indices of these compounds. As can be seen, the four compounds of thymol (39.1\%) (Figure1), p-cymene (20.63\%), Y-Terpinene (14.85\%), and carvacol (4.65\%) constituted an aggregate of $86.54 \%$ of the composition of Thymus Vulgaris essential oil.

The results show that the level of serum glucose has significantly increased in diabetic rats compared to healthy rats [Figure2A]. However, serum glucose levels in the groups receiving thyme extract showed a significant decrease compared to the diabetic group (C2) $(P<0.0001)$. Regarding total serum cholesterol, a significant increase in the cholesterol level was observed in the diabetic control rats at the end of day 18 after the test compared to control group 1 [Table 2]. Thyme hydroalcoholic extract in the studied concentrations causes a significant reduction in total serum cholesterol levels compared to the diabetic control group $(P<0.05)$.

Serum levels of ALT, ALP and AST in the diabetic group increased significantly compared with control group 1 [Figure2B-D]. Also, serum levels of liver enzymes in diabetic groups treated with thyme extract significantly decreased compared to the diabetic group $(P<0.0001)$. Serum levels of liver enzymes in the diabetic group treated with thyme extract at a concentration of $400 \mathrm{mg} / \mathrm{kg}$ body weight significantly decreased, compared with the diabetic group treated with thyme extract at a concentration of 100 and $200 \mathrm{mg} / \mathrm{kg}$ body weight $(\mathrm{P}<0.0001)$. Serum HDL-C levels decreased significantly in the diabetic group compared to the control group and serum LDL-C levels increased significantly [Table 2]. However, in the groups treated with thyme, the levels of HDL-C and LDL-C increased and decreased significantly compared to the diabetic group, respectively $(P<0.05)$. Also, serum levels of VLDL in the diabetic group 
increased significantly compared to control group $1(P<0.05)$. Moreover, serum VLDL levels in the diabetic group treated with thyme extract significantly decreased in comparison to the diabetic group $(P<0.05)$.

\section{Pathology Results}

The results of the present study showed that the number of Kupffer inflammatory cells in the diabetic group increased significantly compared to control group 1. Nonetheless, the number of blood vessels and hepatocytes in the diabetic group decreased significantly compared to control group 1 [Figure 3A and B]. Treatment of diabetic rats with thyme extract, in a dose-dependent manner, led to a significant increase in the number of blood vessels and hepatocytes and also a significant decrease in the number of Kupffer cells compared to the diabetic group [Figure 3C-F]. Comparison of the number of Kupffer cells, blood vessels, and hepatocytes between diabetic groups treated with thyme extract at concentrations of 100 , 200 , and $400 \mathrm{mg} / \mathrm{kg}$ body weight showed a statistically significant difference $(P<0.05)$. Histological examination indicated that the structure of the portal ducts and liver sinusoids is normal in control group 1 and no pathological changes were observed. In the diabetic group, inflammatory cells entered the lobule from the port space. Moreover, severe cell necrosis exists around the port space and there are scattered foci of necrosis in different parts of the liver lobules; also, a noticeable decrease in the number of liver cells, changes in the structure, and irregularity of the liver sinusoids were observed. In the diabetic group treated with concentrations of 100 and $200 \mathrm{mg} / \mathrm{kg}$ of thyme extract, the rate of cell necrosis decreased, compared with the samples in the diabetic group; However, severe inflammation is still seen in the port area. In the diabetic group treated with a concentration of $400 \mathrm{mg} / \mathrm{kg}$ of thyme extract, a decrease in cell necrosis around the port space, a decrease in local inflammation of hepatocytes, and a decrease in hepatic sinusoids irregularity are observed, compared with diabetic samples in which hepatocytes have an almost normal structure.

\section{Real-time PCR Results}

BCL-2 gene expression significantly increased in the diabetic group compared to control group 1, whereas BAX in the diabetic group significantly decreased compared to control group 1 ( $P<0.0001)$. On the other hand, in the groups receiving thyme extract, the expression of BCL-2 decreased and Bax showed a significant increase, compared to the diabetic group without treatment $(P=0.0001)$. Nevertheless, the group receiving $100 \mathrm{mg} / \mathrm{kg}$ body weight of thyme did not show a statistically significant difference when compared to control group 1. Furthermore, the expression of caspase 3 and 9 genes in the diabetic group without treatment showed a significant increase compared to the control group $(P<0.0001)$. However, the expression level of caspase 3 and 9 genes in the diabetic groups treated with thyme extract showed a significant decrease compared to the diabetic control group $(P<0.0001)$ [Figure 4].

\section{Discussion}

Currently, therapies available for treatment of non-insulin dependent diabetes mellitus including improvement of diet, hypoglycemic factors, and insulin, have their own constraints [23]. Investigation on herbal medicine will present a natural key to unlock problems of diabetes in the future. Streptozotocine is 
an antibiotic and anticancer agent that is used in different types of animals to induce diabetes by degeneration and necrosis of pancreatic $\beta$-cells. The liver is one of the organs that is damaged by diabetes. The results of the present study revealed that thyme has a protective effect in STZ diabetic mice against liver tissue damage and reduces liver enzymes and preserves the morphology of liver tissue cells in STZ-receiving mice. The histopathological results of diabetic rats indicated inflammation in the structure of hepatic lobules, so that the infiltration of mononuclear cells and the proliferation of Kupffer cells as well as the departure of Kupffer cells from the sinusoidal wall were observed in the liver tissue sections. Moreover, Kupffer cell accumulation and mononuclear cells were seen around the central vein. Tissue samples in this study showed irregularities in the structure of liver cell plates and central venous dilation in the hepatic lobule of the diabetic group. all of which were decreased by T. Vulgaris. ALT, ALP and AST enzymes are abundant in the liver and any damage to liver cells increases their levels in blood. These enzymes are used to evaluate hepatic disorders. An increase in the activity of the above enzymes reflects damage to the liver. Inflammatory disorders in hepatic cells lead to a sharp rise in transaminase levels $[24,25]$. The results are in accordance with those of other studies in terms of the effects of wild thyme hydroalcoholic extract on hepatic cells and reducing of AST, ALT, and ALP enzymes [26, 27]. According to Yam (2007) and Janbaz (2004), it is proven that caffeic acid prevents the increase of serum enzymes and thus protects against methane tetrachloride-induced hepatic damage. These enzymes prevent liver protection activity through different mechanisms[28, 29]. Bampidis (2005), ALT and AST enzymes decrease by the rise in the antioxidant activity of the liver [30]. According to Matsuura (2003) and Bozin (2006), it appears that due to their antioxidant properties, flavonoid compounds in wild thyme such as Rosemarinic acid are able to neutralize free radicals of 1,1-diphenyl-2-picrylhyrazyl (DPPH) and prevent their destructive effects [31, 32].

T. Vulgaris does not normalize hyperglycemia, suggesting the action of T.Vulgaris on liver dysfunction does not pertain to systemic variables associated with the glucose metabolism. T. Vulgaris, nonetheless, tends to balance out the dyslipidemia in rats with STZ-induced diabetes. T. vulgaris extract proved to have a hypolipidemic effect represented by the decrease on TC as well as LDLC and increase HDL-C levels. When compared to control group 1, BCL-2 gene expression had a significant increase in the diabetic group, while BAX decreased significantly in the diabetic group. Alternatively, when compared to the diabetic group that did not receive treatment, the expression of BCL-2 decreased and the expression of Bax increased significantly in the groups that received thyme extract. Moreover, as compared to the control group, the expression of caspase 3 and 9 genes was significantly higher in the diabetic group without treatment. Nevertheless, as compared to the diabetic control group, the expression levels of caspase 3 and 9 genes in the diabetic groups that received thyme extract were significantly decreased. T. Vulgaris' antiapoptotic potential is sufficient to restore the cells' normal conditions.

Furthermore, stimulation of DNA polymerase by flavonoid compounds causes an increase in rRNA synthesis and results in reconstruction of hepatic cells [33,34]. Based upon Oktem (2006), lithospermic B, 12-hydroxy jasmonic acid, ursolic acid, and other phenolic compounds reduce hepatic inflammations by inhibiting the lipo-oxygenize cycle and preventing leukotrienes and free radicals productions in hepatic kupffer cells in mice [35]. According to the results of Subten Ocak (2007), caffeic acid, one of the 
antioxidant compounds of thyme, prevents high production of nitric oxide and reduces nephrotoxicinduced damage [36]. All the above-mentioned studies confirm the results obtained in this study. Thyme extract contains important antioxidant compounds such as thymol, which can prevent streptococcal damage in liver cells by reducing the expression of apoptosis-related factors. It follows that it can be beneficial for diabetic hepatitis by reducing liver enzymes and improving the morphology of liver tissue cells.

\section{Declarations}

\section{Ethical approval}

Animals use and care were approved with national ethics committee of Tehran University (ethical code: IR.TU.VCR.REC.13992117) and were performed in accordance with the university's guidelines.

Furthermore, all animal experiments comply with the National Institutes of Health guide for the care and use of laboratory animals (NIH Publications No. 8023, revised1978).

\section{Compliance with ethical standards}

Conflict of interest all authors declare that they have no conflict of interest.

\section{Authors' contributions}

$A G$ and $M Z$ wrote the primary draft; $E A, F A, M O$ and $A A$ critically revised the manuscript. All authors read and approved the fnal manuscript.

\section{Data availability}

The datasets used and/or analyzed during the current study are available from the corresponding author on reasonable

\section{References}

1. Chawla A, Chawla R, Jaggi S (2016) Microvasular and macrovascular complications in diabetes mellitus: distinct or continuum? IJEM 20:546

2. Cade WT (2008) Diabetes-related microvascular and macrovascular diseases in the physical therapy setting. Physical therapy 88:1322-1335

3. Akbari M, Hassan-Zadeh V (2018) IL-6 signalling pathways and the development of type 2 diabetes. Inflammopharmacology 26:685-698

4. Bhatt HB, Smith RJ (2015) Fatty liver disease in diabetes mellitus. Hepatobiliary surgery nutrition 4:101

5. Eleazu CO, Eleazu KC, Chukwuma S, Essien UN (2013) Review of the mechanism of cell death resulting from streptozotocin challenge in experimental animals, its practical use and potential risk 
to humans. Journal of diabetes metabolic disorders 12:60

6. Wu J, Yan LJ (2015) Streptozotocin-induced type 1 diabetes in rodents as a model for studying mitochondrial mechanisms of diabetic $\beta$ cell glucotoxicity. Diabetes metabolic syndrome obesity: targets therapy 8:181

7. Raza H, John A (2012) Streptozotocin-induced cytotoxicity, oxidative stress and mitochondrial dysfunction in human hepatoma HepG2 cells. Int J Mol Sci 13:5751-5767

8. Fubini B, Hubbard A (2003) Reactive oxygen species (ROS) and reactive nitrogen species (RNS) generation by silica in inflammation and fibrosis. Free Radic Biol Med 34:1507-1516

9. Bakhshaeshi M, Khaki A, Fathiazad F, Khaki AA, Ghadamkheir E (2012) Anti-oxidative role of quercetin derived from Allium cepa on aldehyde oxidase (OX-LDL) and hepatocytes apoptosis in streptozotocin-induced diabetic rat. Asian Pac J 2:528-531

10. Al-Nahdi AM, John A, Raza H (2018) Cytoprotective Effects of N-Acetylcysteine on StreptozotocinInduced Oxidative Stress and Apoptosis in RIN-5F Pancreatic $\beta$-Cells. Cell Physiol Biochem 51:201216

11. Al-Nahdi AM, John A, Raza H (2019) Streptozotocin-induced molecular and metabolic targets in pancreatic beta-cell toxicity. HMJ 12:65

12. Tan Y, Zhang Z, Zheng C, Wintergerst KA, Keller BB, Cai L (2020) Mechanisms of diabetic cardiomyopathy and potential therapeutic strategies: preclinical and clinical evidence. Nat Rev 17(9):585-607

13. Ferreira FM, Seiça R, Oliveira PJ, Coxito PM, Moreno AJ, Palmeira CM, Santos MS (2003) Diabetes induces metabolic adaptations in rat liver mitochondria: role of coenzyme $Q$ and cardiolipin contents. Biochim Biophys Acta Mol Basis Dis 1639:113-120

14. Björnsson ES, Gu J, Kleiner DE, Chalasani N, Hayashi PH, Hoofnagle JH (2017) Azathioprine and 6mercaptopurine induced liver injury: clinical features and outcomes. J Clin Gastroenterol 51:63

15. Abolghasemi R, Haghighi M, Solgi M, Mobinikhaledi A (2019) Rapid synthesis of ZnO nanoparticles by waste thyme (Thymus vulgaris L.). IJEST 16:6985-6990

16. Ghorbani Ranjbary A, Ghorbani Ranjbary N, Asmarian SH, Ghorbani Ranjbary Z (2012) Effect of origanum vulgare hydroalcoholic extract on liver enzymes, cholesterol, triglycerides, cholesterol-hdl, cholesterol-Idl, total bilirubin, creatinine, albumin, total protein in rat. Res J Pharm Biol Chem Sci 2:121-128

17. Uritu CM, Mihai CT, Stanciu GD, Dodi G, Alexa-Stratulat T, Luca A, Leon-Constantin MM, Stefanescu R, Bild V, Melnic S, Tamba BI (2018) Medicinal plants of the family Lamiaceae in pain therapy: A review. Pain Research and Management. 1-44

18. Ghorbani Ranjbary A, Ghorbani Ranjbary N, Ghorbani Ranjbary Z, Jouibar F (2014) Effects of intraperitoneal injection of extracts of origanum vulgare on gonadotropin and testosterone hormones in male Wistar rats. J Babol Univ Medical Sci 16:57-63

19. Ghorat F, Azizkhani M, Naji S, Ranjbary AG, Doostishoar F (2017) Histopathological evaluation of burdock (Arctium lappa) root hydroalcoholic extract on wound healing. Iran Red Crescent Med J 
19:e43788

20. Villanueva Bermejo D, Angelov I, Vicente G, Stateva RP, Rodriguez García-Risco M, Reglero G, Ibañez $E$, Fornari $T$ (2015) Extraction of thymol from different varieties of thyme plants using green solvents. J Sci Food Agric 95:2901-2907

21. Fecka I, Turek S (2008) Determination of polyphenolic compounds in commercial herbal drugs and spices from Lamiaceae: thyme, wild thyme and sweet marjoram by chromatographic techniques. Food Chem 108:1039-1053

22. Hasan KM, Tamanna N, Haque MA (2018) Biochemical and histopathological profiling of Wistar rat treated with Brassica napus as a supplementary feed. Food science human wellness 7:77-82

23. Pandey A, Tripathi P, Pandey R, Srivatava R, Goswami S (2011) Alternative therapies useful in the management of diabetes: A systematic review. J Pharm Bioallied Sci 3:504

24. El-Newary SA, Shaffie NM, Omer EA (2017) The protection of Thymus vulgaris leaves alcoholic extract against hepatotoxicity of alcohol in rats. Asian Pac J Trop Dis 10:361-371

25. Giannini EG, Testa R, Savarino V (2005) Liver enzyme alteration: a guide for clinicians. Cmaj 172:367-379

26. Kooti W, Kafash-Farkhad N, Ranjbary AG, Sharafi-Ahvazi N (2016) The effect of celery (Apium graveolens) on reproductive parameters in male wistar rat. AJP 6:260

27. Al-Amoudi WM (2017) Protective effects of fennel oil extract against sodium valproate-induced hepatorenal damage in albino rats. Saudi J Biol Sci 24:915-924

28. Yam MF, Basir R, Asmawi MZ, Ismail Z (2007) Antioxidant and hepatoprotective effects of Orthosiphon stamineus Benth. Standardized extract. Am J Chin Med 35:115-126

29. Janbaz KH, Saeed SA, Gilani AH (2004) Studies on the protective effects of caffeic acid and quercetin on chemical-induced hepatotoxicity in rodents. Phytomedicine 11:424-430

30. Bampidis VA, Christodoulou V, Florou-Paneri P, Christaki E, Chatzopoulou PS, Tsiligianni T, Spais AB (2005) Effect of dietary dried oregano leaves on growth performance, carcass characteristics and serum cholesterol of female early maturing turkeys. Brit Poult Sci 46:595-601

31. Matsuura H, Chiji H, Asakawa C, Amano M, Yoshihara T, Mizutani J (2003) DPPH radical scavengers from dried leaves of oregano (Origanum Vulgare). Biosci Biotechnol Biochem 67:2311-2316

32. Bozin B, Mimica-Dukic N, Simin N, Anackov G (2006) Characterization of the volatile composition of essential oils of Some lamiaceae species and the antimicrobial and antioxidant activities of entire oils. J Agric food chem 8:1822-1828

33. Gibson DG, Glass JI, Lartigue C, Noskov VN, Chuang RY, Algire MA, Benders GA, Montague MG, Ma L, Moodie MM, Merryman C (2010) Creation of a bacterial cell controlled by a chemically synthesized genome. Science 329:52-56

34. Sauviac L, Niebel A, Boisson-Dernier A, Barker DG, de Carvalho-Niebel F (2005) Transcript enrichment of Nod factor-elicited early nodulin genes in purified root hair fractions of the model legume Medicago truncatula. J Exp Bot 56:2507-2513 
35. Oktem F, Yilmaz HR, Ozguner F et al (2006) Methotrexate-induced renal oxidative stress in rats: the role of a novel antioxidant caffeic acid phenethyl ester. Toxicol Ind Health 22:241-247

36. Ocak S, Gorur S, Hakverdi S, Celik S, Erdogan S (2007) Protective effects of caffeic acid phenethyl ester, vitamin $\mathrm{C}$, vitamin $\mathrm{E}$ and $\mathrm{N}$-acetylcysteine on vancomycin induced nephrotoxicity in rats. Basic Clin Pharmacol Toxicol 100:328-333

\section{Tables}

Table 1: Main Compounds of Thymus Vulgaris Essential Oil

\begin{tabular}{|c|c|c|c|c|c|c|}
\hline Compound & Percent & *RI & $\begin{array}{l}\text { CHEMICAL } \\
\text { FORMULA }\end{array}$ & $\star \star \mathrm{RT}$ & $\begin{array}{l}\star \star \star \\
\text { LRI }\end{array}$ & IDENTIFICATION \\
\hline a-Pinene & 1.7 & 930 & $\mathrm{C}_{10} \mathrm{H}_{16}$ & 6.76 & 939 & $\mathrm{RI}, \mathrm{MS}$ \\
\hline a-Thujene & 1.41 & 928 & $\mathrm{C}_{10} \mathrm{H}_{16}$ & 7.11 & 936 & $\mathrm{RI}, \mathrm{MS}$ \\
\hline$\beta$-Pinene & 0.64 & 979 & $\mathrm{C}_{10} \mathrm{H}_{16}$ & 14.16 & 984 & RI, MS \\
\hline a-terpinene & 0.4 & 971 & $\mathrm{C}_{10} \mathrm{H}_{16}$ & 11.61 & 985 & $\mathrm{RI}, \mathrm{MS}$ \\
\hline Sabinene & 0.51 & 964 & $\mathrm{C}_{10} \mathrm{H}_{16}$ & 29.96 & 972 & $\mathrm{RI}, \mathrm{MS}$ \\
\hline Borneol & 0.32 & 1172 & $\mathrm{C}_{10} \mathrm{H}_{18} \mathrm{O}$ & 13.68 & 1180 & RI, MS \\
\hline Myrcene & 1.64 & 871 & $\mathrm{C}_{10} \mathrm{H}_{16}$ & 14.62 & 902 & $\mathrm{RI}, \mathrm{MS}$ \\
\hline Thymol & 39.1 & 2010 & $\mathrm{C}_{10} \mathrm{H}_{14} \mathrm{O}$ & 21.50 & 2015 & $\mathrm{RI}, \mathrm{MS}$ \\
\hline Linalool & 0.39 & 1080 & $\mathrm{C}_{10} \mathrm{H}_{18} \mathrm{O}$ & 12.53 & 1085 & $\mathrm{RI}, \mathrm{MS}$ \\
\hline Carvacrol & 4.65 & 1296 & $\mathrm{C}_{10} \mathrm{H}_{14} \mathrm{O}$ & 30.16 & 1330 & $\mathrm{RI}, \mathrm{MS}$ \\
\hline $\begin{array}{l}\text { trans-Sabinene } \\
\text { hydrate }\end{array}$ & 0.2 & 1050 & $\mathrm{C}_{10} \mathrm{H}_{18} \mathrm{O}$ & 15.36 & 1068 & $\mathrm{RI}, \mathrm{MS}$ \\
\hline Pulegone & 36.3 & 1214 & $\mathrm{C}_{10} \mathrm{H}_{16} \mathrm{O}$ & 18.11 & 1221 & RI, MS \\
\hline Bornyl acetate & 0.9 & 1284 & $\mathrm{C}_{12} \mathrm{H}_{20} \mathrm{O}_{2}$ & & 1291 & $\mathrm{RI}, \mathrm{MS}$ \\
\hline p-cymene & 20.63 & 1223 & $\mathrm{C}_{10} \mathrm{H}_{14}$ & 35.40 & 1227 & RI, MS \\
\hline Y-Cadinene & 0.1 & 1531 & $\mathrm{C}_{15} \mathrm{H}_{24}$ & 38.60 & 1535 & $\mathrm{RI}, \mathrm{MS}$ \\
\hline $\mathrm{Y}$-Terpinene & 14.85 & 1050 & $\mathrm{C}_{10} \mathrm{H}_{16}$ & 11.16 & 1060 & RI, MS \\
\hline
\end{tabular}


*RI: retention indices calculated on apolar; ${ }^{*} \mathrm{RT}$ : retention time (min.); ${ }^{\star \star \star} \mathrm{LRI}$ : retention indices of literature

Table 2: Lipid profile of streptozotocin-induced rat's liver injury treated with T. vulgaris leaves alcoholic extract.

\begin{tabular}{|lllll|}
\hline Groups & TC & HDL-C & LDL-C & VLDL \\
\hline Control 1 & $98.36 \pm 2.96$ & $62.5 \pm 3.45$ & $26.35 \pm 2.1$ & $20.72 \pm 1.96$ \\
\hline Control 2 & $120.45 \pm 3.35$ & $49.68 \pm 3.39$ & $31.12 \pm 2.86$ & $24.66 \pm 2.14$ \\
\hline 100 & $115.25 \pm 2.58$ & $55.85 \pm 2.98$ & $29.36 \pm 2.42$ & $22.45 \pm 1.86$ \\
\hline 200 & $109.18 \pm 2.76$ & $60.19 \pm 3.56$ & $27.56 \pm 2.21$ & $21.59 \pm 1.79$ \\
400 & $102.12 \pm 2.47$ & $61.95 \pm 2.15$ & $26.78 \pm 1.84$ & $21.36 \pm 1.44$ \\
\hline
\end{tabular}

Data are presented as the means \pm S.D of Five replicates. Data analyzed by T-test, $P<0.001$, Value with the same letter has no significant but value with different letter has significant at 0.05 . TC; total cholesterol, HDL-C; high density lipoprotein cholesterol, VLDL-C; very low density lipoprotein cholesterol, LDL-C; low density lipoprotein cholesterol.

\section{Figures}

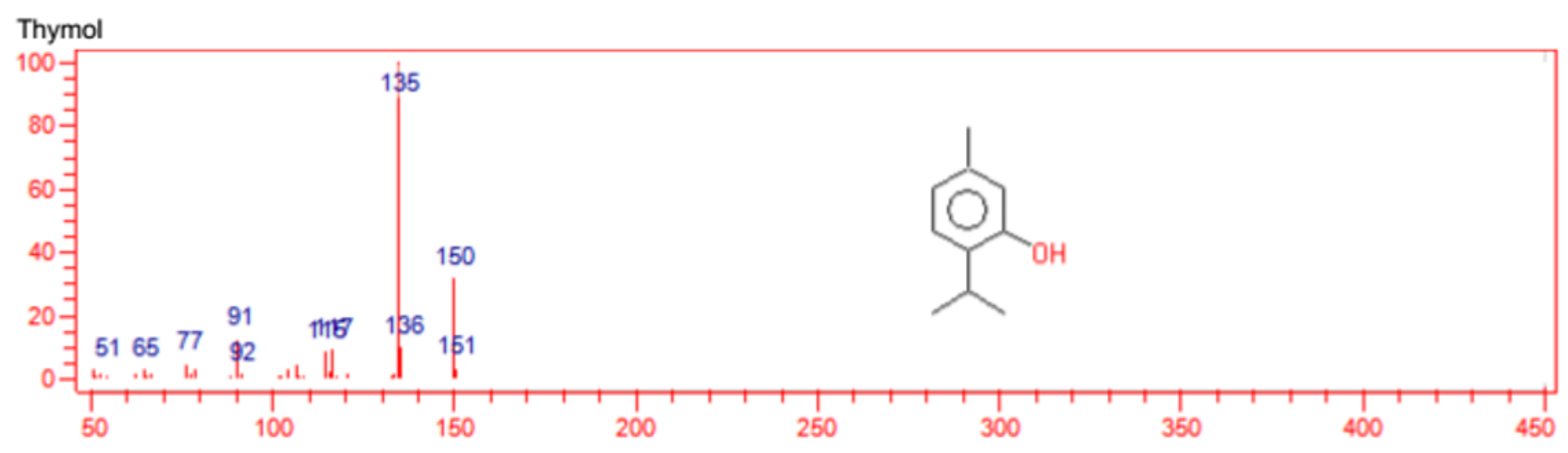

\section{Figure 1}

Thymus vulgaris. viridulum GC/MS chromatogram. Thymol. 
A

B
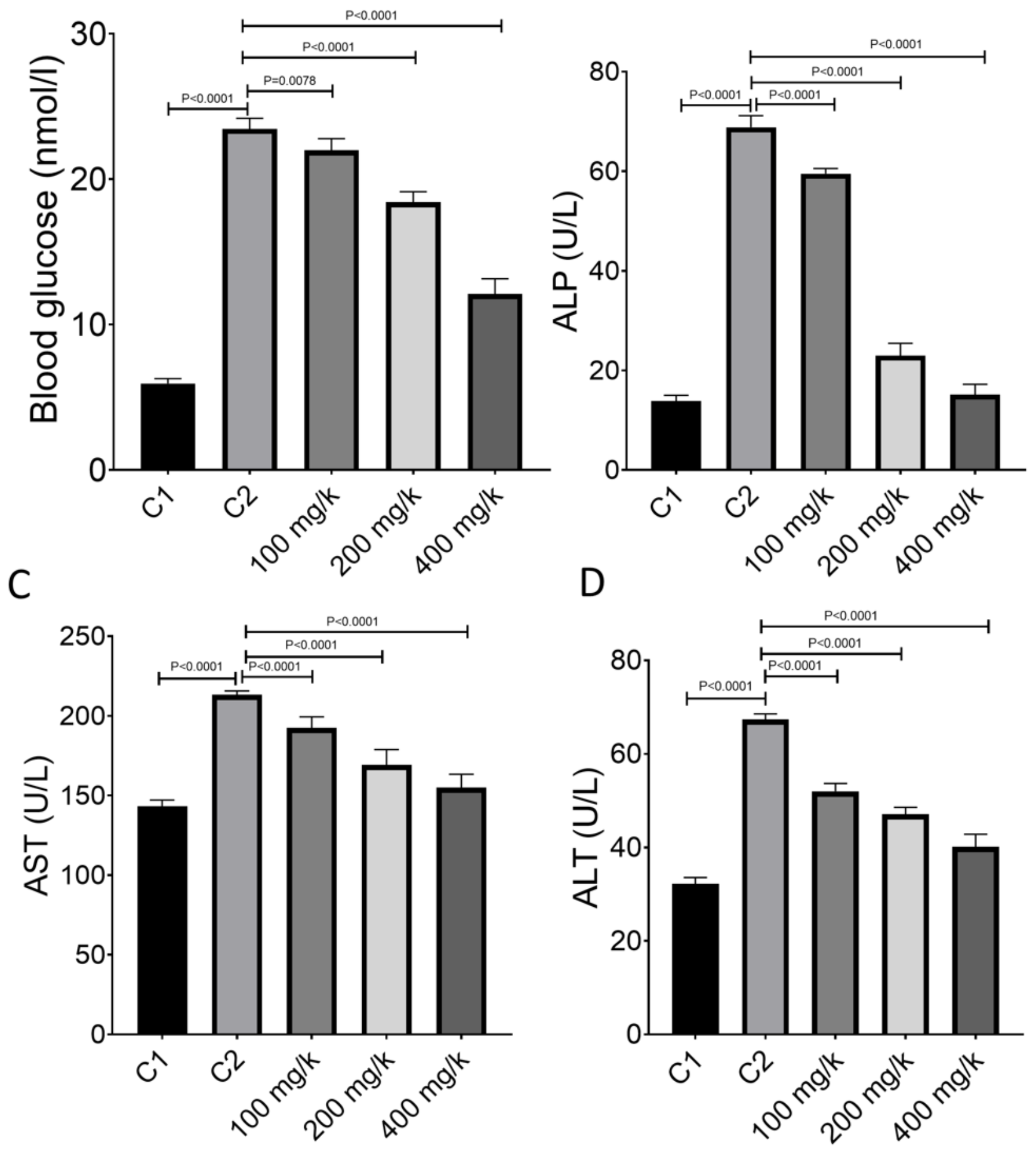

Figure 2

C1) control group, C2) Diabetic group, $100 \mathrm{mg} / \mathrm{k}, 200 \mathrm{mg} / \mathrm{k}$ and $400 \mathrm{mg} / \mathrm{k}$ ) STZ+ Thymus Vulgaris. 


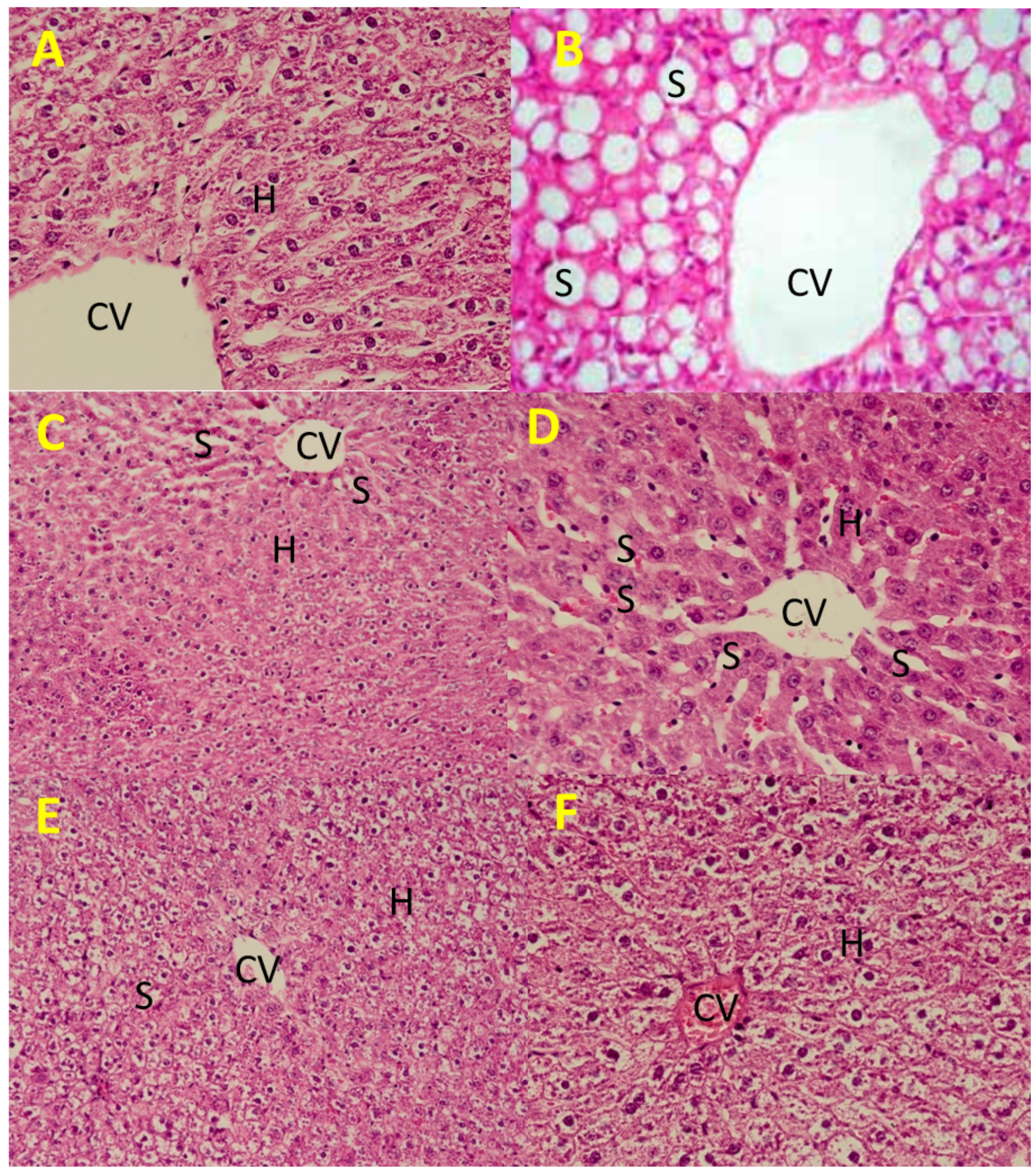

\section{Figure 3}

A photomicrograph of liver sections from: A) negative control rat showed normal structure of liver tissue;

B) control 2(), C-F) Treated rats with extract and STZ showed normalization of liver tissue but with fine dilatation of main blood vessels and sinusoids. CV: Central Venuse Catheter, H: Hepatocyte, S: sinusoid $(H \& E \times 200)$. 


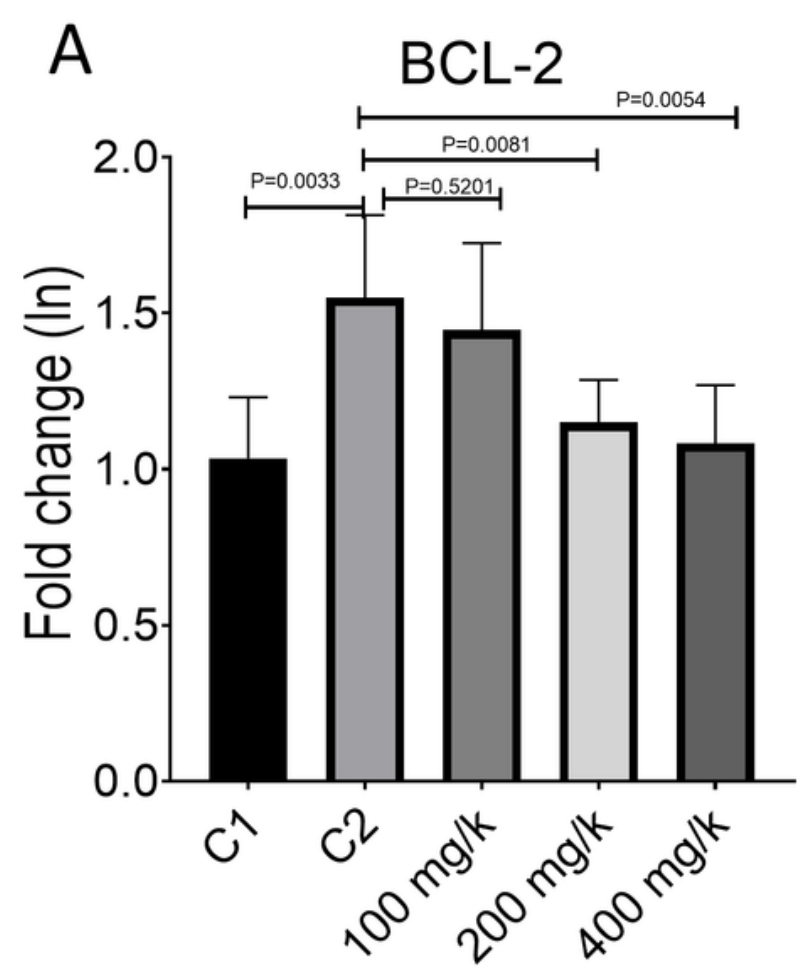

B $\quad$ Bax
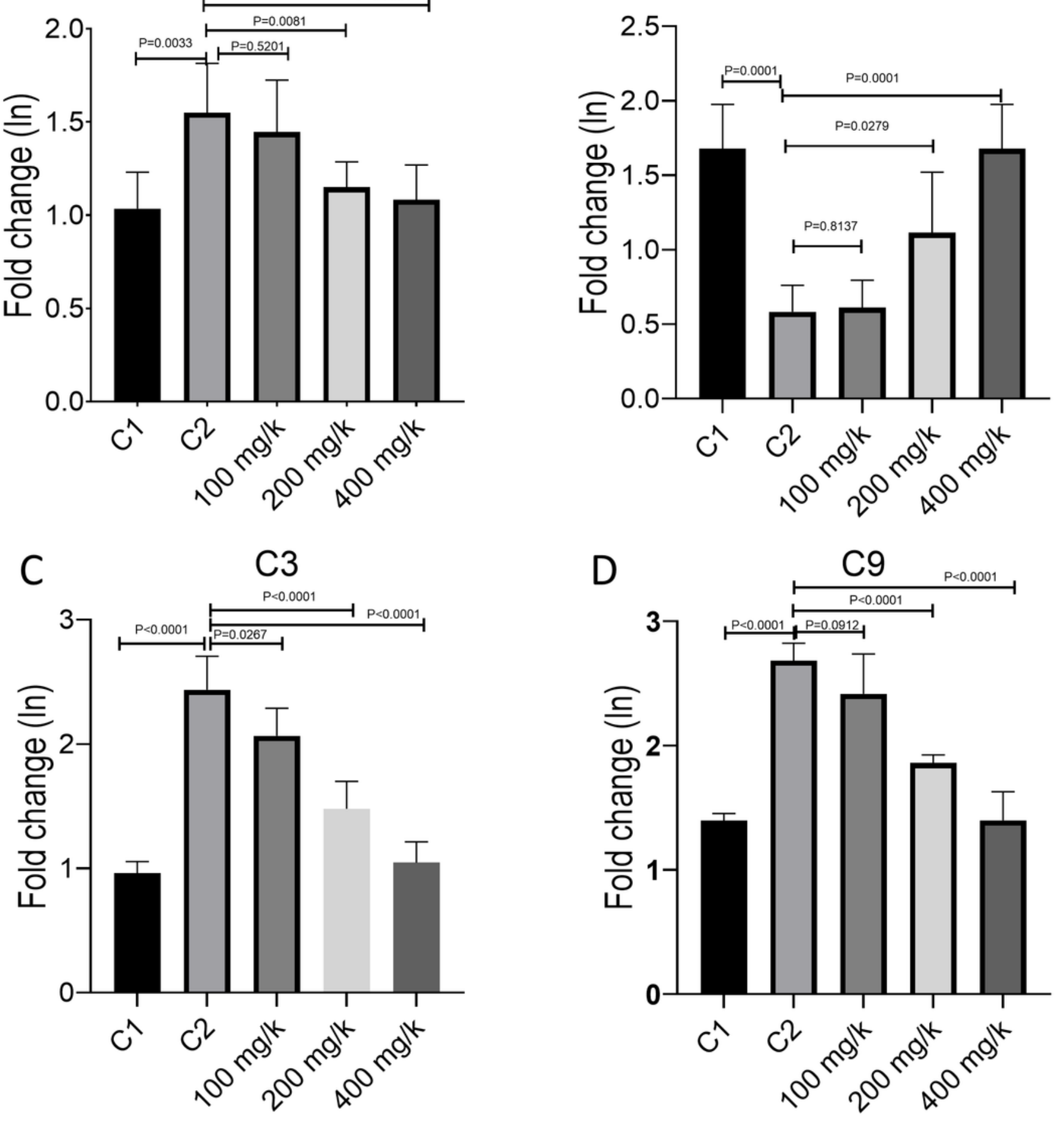

Figure 4

C1) control group, C2) Diabetic group, $100 \mathrm{mg} / \mathrm{k}, 200 \mathrm{mg} / \mathrm{k}$ and $400 \mathrm{mg} / \mathrm{k}$ ) STZ+ Thymus Vulgaris. 